\title{
ERRATUM to: Migration of highly qualified workers and policies to ensure labour market sustainability in the European Union in 2013-2014
}

\author{
Laura Janavičiūtė, Audronė Telešienė, Jurgita Barynienė \\ Kaunas University of Technology, \\ A. Mickevičiaus str. 37, Kaunas \\ cross $^{r e f}$ http://dx.doi.org/10.5755/j01.ppaa.18.3.24731
}

\section{Erratum to: Public policy and Administration (2017), Vol. 6, Nr. 3. DOI: 10.5755/j01.ppaa.16.3.19345}

1. The link to additional reference should be provided

The tasks of the article were set as follows ${ }^{1}:[\ldots]$

${ }^{1}$ This paper is based on master's theses defended by L. Janavičiūte (2017)

2. Reference list must be expanded by:

Janavičiūtè, Laura. The European Union policies for increasing mobility of highly qualified workers: Master's theses in Political Science / supervisor assoc. prof. Audronè Telešienė; Faculty of Social Sciences, Arts and Humanities, Kaunas University of Technology. Kaunas, 2017. $64 \mathrm{p}$.

3. At the bottom of Table 1, the primary source must be provided:

Source: created by Laura Janavičiūtè (2017), based on OECD [33].

4. At the bottom of Table 2, the primary source must be provided:

Source: created by Laura Janavičiūtė (2017), Eurostat [21].

5. At the bottom of Figure 2, the primary source must be provided:

Source: created by Laura Janavičiūtė (2017), Eurostat [21].

6. At the bottom of Figure 3, the primary source must be provided:

Source: created by Laura Janavičiūtė (2017), based on Eurostat [21]

7. At the bottom of Figure 4, the primary source must be provided:

Source: created by Laura Janavičiūtè (2017), based on Eurostat [21] 